\title{
Persistent pain after lateral ankle sprain: A Diagnostic and treatment Dilemma A Review Article
}

\author{
Rajeev Vohra ${ }^{1 *}$, Avtar Singh ${ }^{2}$ and KK Singh ${ }^{3}$ \\ ${ }^{1}$ Senior Consultant and Foot and Ankle Surgeon, Department of Orthopedics, Amandeep Hospital, Amritsar, India \\ ${ }^{2}$ Senior Consultant and Head, Department of Orthopedics, Amandeep Hospital, Amritsar, India \\ ${ }^{3}$ Senior Consultant, Department of Orthopedics, Amandeep Hospital, Amritsar, India \\ *Corresponding author: Rajeev Vohra, Senior Consultant and Foot and ankle surgeon, Department of Orthopaedics,Amandeep \\ Hospital, Model Town, GT Road, Amritsar 143001, India
}

\begin{abstract}
A number of patients continue to experience prolonged pain, swelling, instability and disability after a lateral ankle sprain which is sufficient to limit the activity. There are several conditions which are misdiagnosed as chronic lateral ligament injury. In this review we highlight the common conditions that can mimic chronic lateral ligament injury and can cause persistent ankle pain after lateral ankle sprain. An outline to diagnose and treat these pathologies is also discussed, to resolve the diagnostic and treatment dilemma in most of the patients, but this problem still remains unresolved in a few patients.
\end{abstract}

\section{Introduction}

In an orthopedic or foot and ankle clinic, it is not uncommon to see a patient with persistent ankle pain following an ankle sprain. Most of the patients often remember their affected ankle being forcefully inverted and adducted during the injury leading to lateral ankle sprain. Lateral ankle sprain accounts for $80 \%$ of ankle sprains $[1,2]$ and most of injuries are due to sports [3], but in some patients this injury may be due to falls, slips, or tripping during the routine daily activities [4].

\section{Lateral Ligament Injury}

Acute lateral ligament injury of the ankle vary in its presentation with respect to the amount of pain, swelling, haematoma discolouration, range of motion limitation and loss of function. Although tenderness may have low specificity in lateral ligament injury, a combination of tenderness, hematoma discoloration, and anterior drawer test in the subacute phase ( 5 days after injury) has demonstrated a sensitivity of $96 \%$ and a specificity of $84 \%$ [5].

In most of these patients there is rapid decrease in pain and improvement in function after two weeks of the injury. However, 5 to $33 \%$ of patients continue to have pain at 1 year or longer follow- up with 5 to $25 \%$ still experiencing pain after 3years [6]. Residual problems included pain (30\%), instability (20\%), crepitus (18\%), weakness(17\%), stiffness (15\%), and swelling (14\%) [7]. A severe grade of injury is more likely to produce persistent symptoms, which has been well demonstrated by using an expanded classification [8]. Symptoms often persist, when athletes return to sports without consulting a medical care provider [9]. Apart from the severity of the disease and treatment neglect the other factors like varus heel at heel strike of gait, increased talar curvature, anterior positioning of talus, achillis tendon tightness, and generalised and lateral ligament laxity can contribute to the persistence of symptoms [1017]. Lateral ligament healing after an injury occurs in three different phases (1) inflammatory phase (until 10 days after trauma), (2) the proliferation phase $\left(4^{\text {th }}-8^{\text {th }}\right.$ week $)$ and (3) the remodelling or maturation phase (until 1 year after trauma). The duration of the different phases may individually vary [18].

After inflammatory phase most of the swelling subsides, but there is no significant improvement in ROM deficit [19]. Decreased ankle dorsiflexion leads to abnormal gait pattern due to decreases in step and single leg support time [20]. In addition, proprioceptive 
function might be deficient because mechanoreceptors are damaged by lateral ankle sprain. In addition to decreased range of movement proprioceptive [21] and postural control [22] deficits have been found in acute ankle sprains. A lateral ankle sprain may result in injuries to the lateral musculotendinous structures, peroneus longus and brevis, resulting in tendon tearing, intramuscular strain, or tendon subluxation [23]. The tibialis anterior and extensor digitorum longus and brevis, thought to eccentrically control ankle plantar flexion may be affected. Both peripheral and central reactions of a muscle response are likely too slow to protect against a sudden inversion force [24]. While the ligament is healing after lateral ankle sprain, the ligamentous collagen sequence change leading to the looseness of the ligament [25].

The treatment of the acute phase is implemented with an aim to reduce swelling, improve range of movements, and allowing weight bearing as tolerated. The use of external supports like laceup braces or semi-rigid braces with functional weight bearing significantly reduce time to work and sport and decrease the incidence of subjective instability [26]. Once the acute phase is over the treatment is directed towards progressive loading and sensory motor training to improve mobility strength, coordination and postural control. An inappropriate treatment, or no treatment, and more severe injuries are likely to cause persistent pain. These patients are likely to have recurrent sprains which cause persistent symptoms. $56 \%$ to $74 \%$ patients are reported to have recurrent sprains [27-30]. Patients with recurrent sprains present with pain and crepitus in the ankle and with four or more recurrences have an unstable feeling in the ankle [27].

With repeated recurrences patients develop chronic ankle instability, present with repeated episodes of an unstable feeling of giving away. The chronic ankle instability may be mechanical which is caused by ligament laxity or functional which is caused by proprioceptive deficits, neuromuscular deficits, postural control deficits and muscle weakness [31]. Most often both mechanical and functional instabilities co-exist. Mechanical instability leads to increased talocrural anterior translation and internal rotation as compared to the normal side [32-36]. Chronic lateral ankle sprains are often treated as injuries of the lateral ligament of the ankle, without giving due consideration to lateral sub-talar ligaments. Combined ankle and subtalar instability have been well defined and can lead to severe disability [37]. Stress radiography of the ankle including an anterior drawer and talar tilt are useful for determining both subtalar and ankle instability [38,39]. Magnetic resonance imaging can be used to demonstrate the injured ligaments [40]. Mechanical instability of the talocrural and subtalar joints was found in $24 \%$ to $68 \%$ and $58 \%$ and $58 \%$ respectively [ $41-45$ ].

Proprioceptive deficits, neuromuscular deficits, postural control deficits and muscle weakness lead to functional instability. The alteration of three distinct components: joint position sense, kinesthesia, and force sense has been reported to be responsible for proprioceptive deficits. In a meta-analysis, the patients with chronic ankle instability displayed deficits in joint position sense when compared with patients without chronic ankle instability [46]. Garn and Newton demonstrated a significant decrease in kinesthesia in the injured side when compared with the normal side [47]. As far as force sense is concerned, different studies have shown correlation between error in evertor torque and chronic ankle instability [48-50]. A significant delay in the reaction time of peroneus muscles point towards the association of neuromuscular deficits with chronic ankle instability [51]. A significant decrease in static postural control have been suggested in chronic instability $[52,53]$.

Ankle instability is primarily a clinical diagnosis and stress radiography might be more appropriate as an adjunctive test for patients for whom the history and physical examination findings are equivocal. MRI has high sensitivity but low specificity in the evaluation of clinical ankle instability [54]. While MRI has value as a screening tool for concomitant ankle pathology, it should not be considered diagnostic in terms of lateral ankle instability [55].

A course of physical therapy is indicated as the first line of treatment to treat chronic lateral ligament instability, whether functional or mechanical. When conservative management is not successful, surgical intervention can be employed successfully with high, predictable rates [56]. The lateral ligament repair is widely accepted as the primary operative treatment for chronic lateral ankle instability. Both arthroscopic and non-arthroscopic techniques used for repairing have yielded good results. Arthroscopy is usually done at the time of lateral ligament repair to rule out any intra- articular pathology, however in the patient without pain and negative MRI arthroscopy may not be necessary [57]. The traditional Brostrom and modified Brostrom-Gould repair are two historically reliable procedures known to provide sufficient biomechanical stability [58-62]. Various techniques like trans-osseous sutures, single and double suture anchors and direct suture to fibular periosteum have been found effective in reattachment of the lateral ligament $[63,64]$. Recently arthroscopic repair is becoming popular and reattachment of ligament and capsule performed with one or two anchors have shown excellent results [65-68]. These procedures are less invasive and allow faster return to normal and sports activities. In a recent systematic review comparing open and arthroscopic lateral ligament repair for chronic ankle stability both procedures were found to be equally reproducible and safe [69]. Whether the repair is done arthroscopically or by open method, arthroscopy at the time of repair is usually done to rule out associated intraarticular lesions often found in $63-95 \%$ of the cases [70-74]. In order to accelerate the recovery process and provide extra stability particularly in high level athletes augmentation of the repair by transferring of half of the peroneus brevis to the fibula [75], or an internal brace has been recommended [76].

In certain subgroups such as heavier athletes, revision cases and patients with ligamentous laxity, hindfoot varus, or inadequate residual ligament for direct repair, ligament repair is not possible or 
inefficient. Historically several non-anatomic techniques requiring sacrifice of local tissues or peroneal tendons, like Evans [77], the Chrisman-Snook [78], the Watson-Jones [79] and the Castaing procedure [80] have been used in these situations. Nonanatomic procedures have largely been abandoned because of excessive peroneal weakness, stiffness of the subtalar joint and ankle degeneration [71,81]. Recently anatomic ligament reconstruction using free autograft or allograft tendons has become popular in these circumstances. This reconstruction re-creates the anatomic orientation of anterior talofibular ligament and calcaneofibular ligament and provides the required ankle stability [82-85].

\section{Other Ligamentous Injuries}

Chronic lateral ankle sprains are often treated as injuries of the lateral ligament of the ankle, without giving due consideration to the other ligaments around ankle like lateral sub-talar ligaments, syndesmotic ligaments and deltoid ligament. Combined lateral ankle ligament and syndesmotic Injuries do occur when an external rotation injury accompanies an ankle inversion, although external rotation remains the most common mechanism associated with syndesmotic injury [86]. It has been reported that a high-grade injury to the syndesmosis is typically associated with minimally traumatized lateral ankle ligaments, where as a lowgrade injury may be associated with concurrent low- and high-grade lateral ligament sprains [87]. In a cross-sectional MRI study $20.3 \%$ athletes referred for MRI after suffering an acute ankle sprain had evidence of syndesmotic injury regardless of lateral ligament involvement [88]. In the presence of supra-malleolar edema and pain with passive dorsiflexion and external rotation of the ankle syndesmotic injury should be suspected. A chronic, symptomatic and an unstable syndesmosis on stress tests and/or arthroscopy needs syndesmotic reduction and fixation, by screws, suture buttons, or a combination of the two [86]. In the presence of frank diastasis open debridement and reconstruction using fixation or reconstruction of ligaments using hamstring autografts or allografts, or peroneus longus had been suggested [89-91]. In neglected cases with severe incongruity, or a recurrence of diastasis after removal of fixation arthrodesis of the distal tibiofibular joint remains another option, however ankle arthritis and pain following arthrodesis remains a genuine concern [92-94].

Because of the internal talar rotation related with lateral ankle instability, many athletes with significant lateral ligament injury have been found to have deltoid ligament abnormality on arthroscopy and MR imaging $[95,96]$. In patients with combination of chronic ankle instability and medial and lateral ankle pain $40 \%$ of patients are found to have deltoid injury [97]. Tibiocalcaneal component of the deltoid complex is most commonly involved, but in some patients additional avulsion of the deep anterior tibiotalar component is reported [97]. Ankle repair of both sides of the ankle is required in these cases to provide adequate stability.

\section{Impingement Syndromes}

Following an inversion injury of the ankle a combination of lateral ligament injury and anterior inferior tibiofibular ligament may lead to inflammation in proximity of the healing ligaments and subsequent synovitis and scar tissue formation [98]. The entrapment of this hypertrophic soft tissue or torn and inflamed ligaments in the lateral gutter and anterolateral ankle joint produces ankle pain due to anterolateral ankle impingement [99]. Anterolateral impingement is suspected in the presence of tenderness at the joint line lateral to peroneus tertius [100] and can be further assessed by MR imaging which can detect the presence of anterolateral soft tissue pathology as well as rule out associated pathologies like osteochondral lesions, loose bodies and stress fractures [101-103]. Currently open resection for anterolateral impingement has been replaced by arthroscopic resection due to complications as low as $3.5 \%$ with arthroscopy $[104,105]$.

\section{Peroneal Tendon Injuries}

Following an excessive ankle inversion apart from injuries to lateral ligament, subtalar, medial and syndesmotic structures, injuries to peroneal tendons can occur. A variety of peroneal tendon pathologies like tenosynovitis, fraying, longitudinal fissuring, partial and full-thickness tears, ruptures, and peroneal tendons subluxations and dislocations have been reported [106]. Persistent posterolateral or posterior hindfoot pain, swelling, tenderness and thickening along the peroneal tendons should prompt the surgeon to consider peroneal tendon pathology as a possible contributor to pain [107]. Pain with resisted eversion, passive inversion stretches and resisted plantar flexion of first metatarsal is present on clinical examination [108]. In the presence of peroneal tendon instability patients report a snapping and popping or giving way in the ankle and subluxation can be recreated via forced dorsiflexionor resisted plantar flexion and inversion [109]. Longitudinal and acute tears of the peroneal tendons require debridement, tubularization, or end to end repair [107]. When one of the peroneal tendons is irreparable the surgical options include tenodesis to the adjacent functional tendon or bridging the defect using allografts or autografts, and the salvage of both irreparable tendons may require allografts or autografts, or tendon transfer [110]. A variety of surgical methods available for peroneal tendon subluxation or dislocation include enhanced repair of the superior peroneal retinaculum, transposition of soft tissues, tendon rearrangement, bone blocking and groove deepening [111-115].

\section{Osteochondral Lesions}

Osteochondral lesion of the ankle is another common injury following an ankle sprain, caused by rotation of talus in the ankle mortise during inversion injury [116]. An ankle positioned in inversion and dorsiflexion predisposes for an osteochondral lesion on the lateral side, while medial lesions occur mostly with the ankle positioned in inversion and plantar flexion [117]. Osteochondral lesions associated with chronic lateral ankle instability are larger $(150 \mathrm{~mm} 2$ or larger) in ankles without chronic lateral ankle 
instability, and additional chondral lesions at the tip of the medial malleolus and the tibia plafond [118]. Osteochondral lesion of the ankle should be suspected when symptoms like dull and deep ankle pain, swelling, restriction of ankle movements, locking or crepitus persist following treatment of ankle inversion injuries. Because clinical findings are mostly non-specific imaging is often required to establish the diagnosis and accurately describe the anatomy of the lesion. Radiography alone is insufficient to detect all lesions and cannot provide the necessary details required to plan the treatment. Most often CT Scan, or MRI or a combination of both is required to establish the precise characteristics of the lesion and classify it. CT Scan provides information about the size shape and displacement of bony injury and MRI is used to evaluate the cartilage $[119,120]$. MRI can detect articular injury with morphological abnormality, but degenerative changes without morphological change are missed even in MR imaging. Arthroscopy allows the surgeon to diagnose such lesions by probing the articular surface and feeling for fissures [121]. In a study sensitivity and specificity for detecting an OCD with arthroscopy were 100 and 97\%, respectively, and sensitivity and specificity values for MRI were 96 and $96 \%$, and 81 and $99 \%$ for CT [122]. Size, location, type, stability, displacement, and containment of the lesion are important factors in deciding the treatment [123].

Asymptomatic lesions or the lesions detected incidentally are kept under observation. Minimally symptomatic lesions may be treated non-operatively with rest, ice and temporarily reduced weight bearing [124]. For lesions up to $15 \mathrm{~mm}$ in diameter reparative strategy by marrow stimulation using microfracture technique is recommended which is often performed arthroscopically [125-127]. Large cystic lesions with more or less intact cartilage are amenable to retrograde drilling to induce subchondral revascularization and stimulate new bone formation, and when lesions are difficult to approach due to their location antegrade transmalleolar drilling may be used [127-130]. Choi et al. [131] assessed the effect of the size of the lesion on the clinical outcomes and patients with lesions more than $15 \mathrm{~mm}$ in diameter had worst outcomes [131]. A number of replacement surgeries which are done arthroscopically or performed through open surgery, depending upon the size and location of the lesion are available for larger lesions. These options include osteochondral allograft transplantation [132], osteochondral autograft transplantation [133], autologous chondrocyte implantation [134], matrix induced chondrocyte implantation $[134,135]$, juvenile articular cartilage transplantation [134,136], particulated autograft cartilage implantation [137].

\section{Osseous Injuries}

During inversion injury of the ankle anterior talofibular ligament is mostly ruptures in its mid substance but in some cases this mechanism of injury can lead to avulsion fractures of distal fibula or talus [138]. Haraguchi et al. [139] noted avulsion fractures in $26 \%$ of the patients with severe inversion injury, with a $36 \%$ nonunion rate after conservative treatment, but comparable between avulsion fracture groups and ligament rupture groups [139]. Large gaps in avulsion fracture of lateral malleolar tip may cause chronic pain and instability [140]. Symptomatic ossicles without instability may require excision [141]. In the presence of instability the symptomatic ossicles need excision and concomitant repair of lateral ankle ligaments [142]. In a recent study of 10 patients with avulsion fractures of lateral malleolar tip explored arthroscopically after a mean of 7.7 days (range 2-17 days) of injury, anterior talofibular ligament and calcaneofibular ligament were found to be attached to the avulsed fragment. The authors suggested primary fixation with screws and found it to be an efficient treatment to restore function and stability [143].

An inversion injury can cause avulsion fracture of lateral process of talus through lateral talocalcaneal ligament attachment [144]. Up to $40 \%$ of lateral process fractures are missed on initial presentation [145]. Tenderness anterior and inferior to the lateral malleolus should raise the suspicion for this fracture. If there is a high index of suspicion, then CT Scan or MRI scan should be done to establish the exact diagnosis. Neglected or insufficiently treated fractures can cause long term disability $[146,147]$. Complications of fractures of lateral process of talus include severe degenerative subtalar arthritis, nonunion, and impingement on calcaneus and fibula due to overgrowth of the lateral process. Large displaced fractures involving articular surface need open reduction and internal fixation, and non-reconstructible fragments need to be excised $[144,148]$. In a chronically neglected fracture with arthritis of subtalar joint, subtalar fusion may be required [148].

Avulsion fracture of the anterior process of the calcaneus is another supination injury which is often missed in the initial stages [149]. Dorsal attachment of bifurcate ligament can cause this avulsion fracture [150]. Extensor brevis muscle attachment lateral to bifurcate ligament can also cause large wedge or flake shaped avulsion fracture [151]. Most injuries heal uneventfully, and in patients with persistent complaints resection of small avulsion fracture carries a minimal risk and appears to have a significant benefit [150]. Dorsal talar and navicular avulsion fractures are uncommonly seen in patients presenting with lateral ankle sprain [152]. Dorsal talonavicular ligament and the anterior tibiotalar ligament when injured can avulse causing a small bony injury [153]. Most injuries do not warrant any specific treatment but missed diagnosis can be an overly concern that a fracture was missed, which can lead to confusion and anxiety $[153,154]$. It is important to palpate dorsal surface of talus and navicular in patients presenting with lateral ankle sprain to avoid missing these injuries.

Avulsion fracture of the base of the fifth metatarsal is another common osseous injury associated with inversion injury of the ankle. It is due to forces exerted on the base by the attachment of the peroneus brevis and lateral aponeurosis [155]. Most fractures heal with a walking boot or cast. Neglected or inappropriately treated injuries may lead to painful non-unions, which require excision of the small fragment and repair of the peroneus brevis and fixation 
and grafting of the large fragments [156].

\section{Sinus Tarsi Syndrome}

Pain directly over the sinus tarsi following an inversion injury of the ankle may be due to sinus tarsi syndrome. Interosseous ligament injury, hypertrophy of the synovium, or hypertrophy of the fat resulting in impingement of the neural plexus are the possible reasons for the pain [144]. Pain relief after an injection of local anaesthetic into the sinus tarsi can be diagnostic as well as therapeutic. Open or arthroscopic debridement of the contents of the sinus tarsi is required sometimes.

\section{Conclusion}

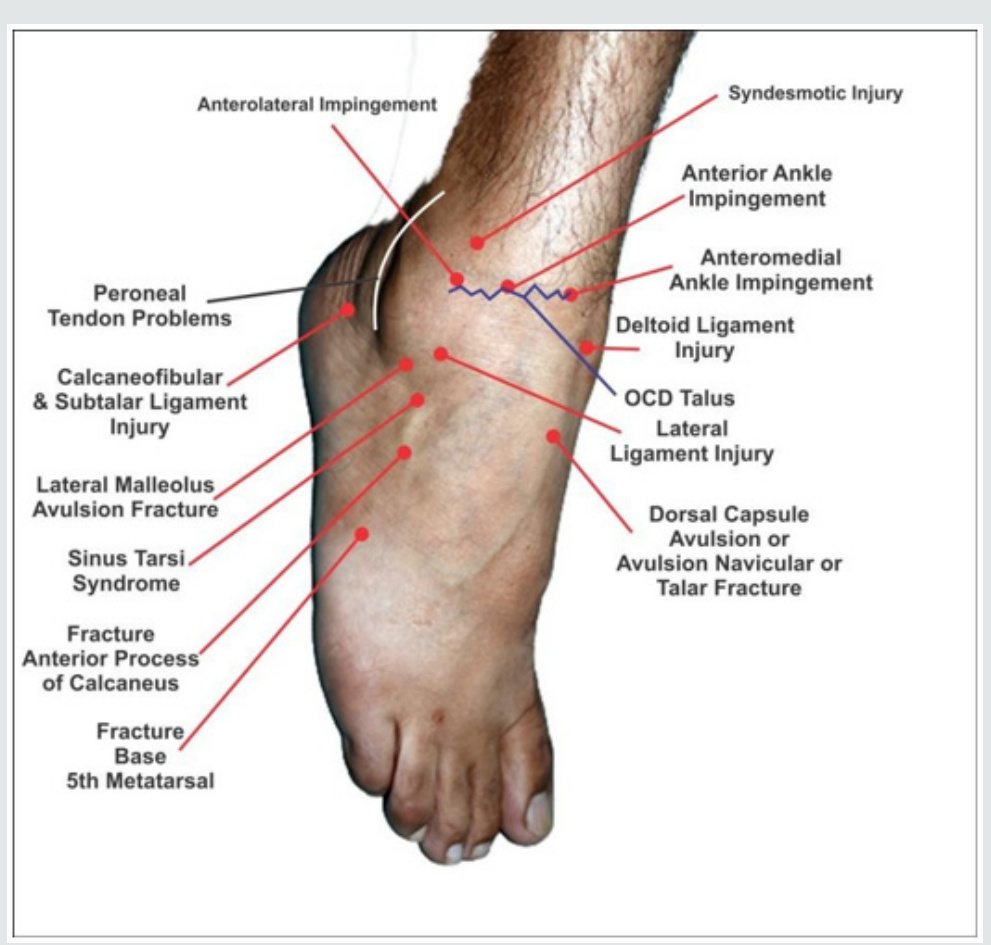

Figure 1: Injuries seen with inversion sprain of the foot and possible sites of tenderness.

An inversion injury of the foot may cause damage to a number of important structures apart from lateral ligament of the ankle. It is essential to have a sound anatomical knowledge of the foot and ankle and a routine examination should include the palpation of various structures as shown in the Figure 1. A structured examination of ligaments, osseous, chondral, muscular and tendinous structures around the lateral malleolus is suggested to locate the exact cause of pain. It is not uncommon to have combined injuries of the abovementioned structures in one individual. Apart from the systematic examination MRI is a very helpful in reaching the exact diagnosis. In spite of increase in knowledge of the foot and ankle anatomy and advances in imaging techniques the problem of persistent pain after lateral ankle sprain still remains in a few cases.

\section{References}

1. Gerber JP, Williams GN, Scoville CR, Arciero RA, Taylor DC (1998) Persistent disability associated with ankle sprains: A prospective examination of an athletic population. Foot Ankle Int 19(10): 653-660.

2. Woods C, Hawkins R, Hulse M, Hodson A (2003) The football association medical research programme: An audit of injuries in professional football: An analysis of ankle sprains. Br J Sports Med 37(3): 233-238.

3. Fong DT, Hong Y, Chan LK, Yung PS, Chan KM (2007) A systematic review on ankle injury and ankle sprain in sports. Sports Med 37(1): 73-94.
4. Braun BL (1999) Effects of ankle sprain in a general clinic population 6 to 18 months after medical evaluation. Arch Fam Med 8(2): 143-148.

5. van DijkCN, Lim LS, Bossuyt PM, Marti RK (1996) Physical examination is sufficient for the diagnosis of sprained ankles. J Bone Joint Surg Br 78(6): 958-962.

6. van Rijn RM, van Os AG, Bernsen RM, Luijsterburg PA, Koes BW, et al. (2008) What is the clinical course of acute ankle sprains? A systematic literature review. Am J Med 121(4): 324- 331.

7. Fong DT, Chan YY, Mok KM, Yung P, Chan KM (2009) Understanding acute ankle ligamentous sprain injury in sports. Sports Med Arthrosc Rehabil Ther Technol 30: 1-14.

8. Malliaropoulos N, Papacostas E, Papalada A, Maffulli N (2006) Acute lateral ankle sprains in track and field athletes: An expanded classification. Foot Ankle Clin 11(3): 497-507.

9. Hubbard TJ, Cordova M (2009) Mechanical instability after an acute lateral ankle sprain. Arch Phys Med Rehabil 90(7): 1142-1146.

10. Hiller CE, Nightingale EJ, Lin CW, Coughlan GF, Caulfield B, et al. (2011) Characteristics of people with recurrent ankle sprains: A systematic review with meta-analysis. Br J Sports Med 45(8): 660-672.

11. Magerkurth O, Frigg A, Hintermann B, Dick W, Valderrabano V (2010) Frontal and lateral characteristics of the osseous configuration in chronic ankle instability. Br J Sports Med 44(8): 568- 572.

12. Van Bergeyk AB, Younger A, Carson B (2002) CT analysis of hindfoot alignment in chronic lateral ankle instability. Foot Ankle Int 23(1): 3742. 
13. Wikstrom EA, Hubbard TJ (2010) Talar positional fault in persons with chronic ankle instability. Arch Phys Med Rehabil 91(8):1267-1271.

14. Drewes LK, McKeon PO, Kerrigan DC, Hertel J (2009) Dorsiflexion deficit during jogging with chronic ankle instability. J Sci Med Sport 12(6): 685687.

15. Baumhauer JF, Alosa DM, Renstrom AF, Trevino S, Beynnon BA (1995) Prospective study of ankle injury risk factors. Am J Sports Med 23(5): 564-570.

16. Hiller CE, Refshauge KM, Herbert RD, Kilbreath SL (2008) Intrinsic predictors of lateral ankle sprain in adolescent dancers: a prospective cohort study. Clin J Sport Med 18(1): 44-48.

17. Beynnon BD, Renstrom PA, Alosa DM, Baumhauer JF, Vacek PM (2001) Ankle ligament injury risk factors: A prospective study of college athletes. J Orthop Res 19(2): 213-220.

18. Houglum PA (1992) Soft tissue healing and its impact on rehabilitation. J Sport Rehabil 1(1): 19-23.

19. Wilson RW, Gieck JH, Gansneder BM, Perrin DH, Saliba EN, et al. (1998) Reliability and responsiveness of disablement measures following acute ankle sprains among athletes. J Orthop Sports Phys Ther 27(5): 348-355.

20. Crosbie J, Green T, Refshauge K (1999) Effects of reduced ankle dorsiflexion following lateral ligament sprain on temporal and spatial gait parameters. Gait Posture 9(3): 167-172.

21. Konradsen L, Olesen S, Hansen HM (1998) Ankle sensorimotor control and eversion strength after acute ankle inversion injuries. Am J Sports Med 26(1): 72-77.

22. McKeon PO, Hertel J (2008) Systematic review of postural control and lateral ankle instability, part I: can deficits be detected with instrumented testing. J Athl Train 43(3): 293-304.

23. Dombek MF, Lamm BM, Saltrick K, Mendicino RW, Catanzariti AR (2003) Peroneal tendon tears: A retrospective review. J Foot Ankle Surg 42(5): 250-258.

24. Konradsen L, Voigt M, Hojsgaard C (1997) Ankle inversion injuries. The role of the dynamic defense mechanism. Am J Sports Med 25(1): 54-58.

25. Hubbard TJ, Hertel J (2006) Mechanical contributions to chronic lateral ankle instability. Sports Med 36(3): 263-277.

26. Kerkhoffs GM, Rowe BH, Assendelft WJ, Kelly KD, Struijs PA, et al. (2001) Immobilisation for acute ankle sprain. A systematic review. Arch Orthop Trauma Surg 121(8): 462-471.

27. Yeung MS, Chan KM, So CH, Yuan WY (1994) An epidemiological survey on ankle sprain. Br J Sports Med 28(2): 112-116.

28. Swenson DM, Yard EE, Fields SK, Comstock RD (2009) Patterns of recurrent injuries among US high school athletes, 2005-2008. Am J Sports Med 37(8): 1586-1593.

29. Nielsen AB, Yde J (1989) Epidemiology and traumatology of injuries in soccer. Am J Sports Med 17(6): 803-807.

30. McKay GD, Goldie PA, Payne WR, Oakes BW (2001) Ankle injuries in basketball: Injury rate and risk factors. Br J Sports Med 35(2): 103-108.

31. Hertel J (2002) Functional anatomy, pathomechanics, and pathophysiology of lateral ankle instability. J Athl Train 37(4): 364-375.

32. Bahr R, Pena F, Shine J, Lew WD, Lindquist C, et al. (1997) Mechanics of the anterior drawer and talar tilt tests. A cadaveric study of lateral ligament injuries of the ankle. Acta Orthop Scand 68(5): 435-441.

33. Bulucu C, Thomas KA, Halvorson TL, Cook SD (1991) Biomechanical evaluation of the anterior drawer test: The contribution of the lateral ankle ligaments. Foot Ankle 11(6): 389-393.

34. Kjaersgaard-Andersen P, Frich LH, Madsen F, Helmig P, Søgård P, et al. (1991) Instability of the hindfoot after lesion of the lateral ankle ligaments: investigations of the anterior drawer and adduction maneuvers in autopsy specimens. Clin Orthop Relat Res May 266: 170179.
35. Rosenbaum D, Becker HP, Wilke HJ, Claes LE (1998) Tenodeses destroy the kinematic coupling of the ankle joint complex. A three-dimensional in vitro analysis of joint movement. J Bone Joint Surg Br 80(1): 162-168.

36. Caputo AM, Lee JY, Spritzer CE, Easley ME, Derio JK, et al. (2009) In vivo kinematics of the tibiotalar joint after lateral ankle instability. Am J Sports Med 37(11): 2241-2248.

37. Peterson KS, Catanzariti AR, Mendicino MR, Mendicino RW (2013) Surgical approach for combined ankle and subtalarchronic mechanical instability. J Foot Ankle Surg 52(4): 537-542.

38. DiGiovanni CW, Brodsky A (2006) Current concepts: lateral ankle instability. Foot Ankle Int 27(10): 854-866.

39. Laurin CA, Ouellet R, St-Jacques R (1968) Talar and subtalar tilt: an experimental investigation. Can J Surg 11(3): 270-279.

40. Ahmad MA, Pandey UG, Crerand JJ, al-Shareef Z, Lapinsuo M (1998) Magnetic resonance imaging of the normal and injured lateral collateral ligaments of the ankle. Ann Chir Gynaecol 87(4): 311-316.

41. Lentell G, Baas B, Lopez D, McGuire L, Sarrels M, et al. (1995) The contributions of proprioceptive deficits, muscle function, and anatomic laxity to functional instability of the ankle. J Orthop Sports Phys Ther 21(4): 206-215.

42. Lofvenberg R, Karrholm J, Lund B (1994) The outcome of nonoperated patients with chronic lateral instability of the ankle: A 20-year follow-up study. Foot Ankle Int 15(4): 165-169.

43. Ryan L (1994) Mechanical stability, muscle strength and prorioception in the functionally unstable ankle. Aust J Physiother 40(1): 41-47.

44. Tropp H, Odenrick P, Gillquist J (1985) Stabilometry recordings in functional and mechanical instability of the ankle joint. Int J Sports Med 6(3): 180-182.

45. Hertel J, Denegar CR, Monroe MM, Stokes WL (1999) Talocrural and subtalar joint instability after lateral ankle sprain. Med Sci Sports Exerc 31(11): 1501-1508.

46. McKeon JM, McKeon PO (2012) Evaluation of joint position recognition measurement variables associated with chronic ankle instability: A meta-analysis. J Athl Train 47(4): 444-456.

47. Garn SN, Newton RA (1988) Kinesthetic awareness in subjects with multiple ankle sprains. Phys Ther 68(11): 1667-1671.

48. Arnold BL, Docherty CL (2006) Low-load eversion force sense, selfreported ankle instability and frequency of giving way. J Athl Train 41(3): 233-238.

49. Docherty CL, Arnold BL, Hurwitz S (2006) Contralateral force sense deficits are related to the presence of functional ankle instability. J Orthop Res 24(7): 1412-1419.

50. Wright CJ, Arnold BL (2012) Fatigue's effect on eversion force sense in individuals with and without functional ankle instability. J Sport Rehabil 21(2): $127-136$

51. Hoch MC, McKeon PO (2014) Peroneal reaction time following ankle sprain: A systematic review and meta-analysis. Med Sci Sports Exerc 46(3): 546-556

52. Arnold BL, De La Motte S, Linens S, Ross SE (2009) Ankle instability is associated with balance impairments: a meta-analysis. Med Sci Sports Exerc 41(5): 1048-1062.

53. Hiller CE, Nightingale EJ, Lin CW, Coughlan GF, Caulfield B, et al. (2011) Characteristics of people with recurrent ankle sprains: A systematic review with meta-analysis. Br J Sports Med 45(8): 660-672.

54. Jeong BO, Kim TY, Song WJ (2016) Effect of preoperative stress radiographic findings on radiographic and clinical outcomes of the modified brostrom procedure for chronic ankle instability. J Foot Ankle Surg 55(1): 125-128.

55. Jolman S, Robbins J, Lewis L, Wilkes M, Ryan P (2017) Comparison of magnetic resonance imaging and stress radiographs in the evaluation of chronic lateral ankle instability. Foot Ankle Int 38(4): 397-404. 
56. Shakked RJ, Karnovsky S, Drakos MC (2017) Operative treatment of lateral ligament instability. Curr Rev Musculoskelet Med 10(1): 113-121.

57. Orr JD, Robbins J, Waterman BR (2014) Management of chronic lateral ankle instability in military service members. Clin Sports Med 33(4): 675-692.

58. Brostrom L (1966) Sprained ankles. VI. Surgical treatment of "chronic" ligament ruptures. Acta Chir Scand 132(5): 551-565.

59. Bell SJ, Mologne TS, Sitler DF, Cox JS (2006) Twenty-six-year results after Brostrom procedure for chronic lateral ankle instability. Am J Sports Med 34(6): 975-978.

60. Gould N, Seligson D, Gassman J (1980) Early and late repair of lateral ligament of the ankle. Foot Ankle 1(2): 84-89.

61. Hamilton WG, Thompson FM, Snow SW (1993) The modified Brostrom procedure for lateral ankle instability. Foot Ankle 14(1): 1-7.

62. Behrens SB, Drakos M, Lee BJ, Paller D, Hoffman E, et al. (2013) Biomechanical Analysis of Brostrom Versus Brostrom-Gould Lateral Ankle Instability Repairs. Foot Ankle Int 34(4): 587-592.

63. Cho BK, Kim YM, Kim DS, Choi ES, Shon HC, et al. (2012) Comparison between suture anchor and transosseous suture for the modifiedBrostrom procedure. Foot Ankle Int 33(6): 462-468.

64. Cho BK, Kim YM, Kim DS, Choi ES, Shon HC, et al. (2013) Outcomes of the modified Brostrom procedure using suture anchors for chronic lateral ankle instability. A prospective, randomized comparison between single and double suture anchors. J Foot \& Ankle Surg 52(1): 9-15.

65. Nery C, Raduan F, Del Buono A, Asaumi ID, Cohen M, et al. (2011) Arthroscopic- assisted brostrom gould for chronic ankle instability: A long-term follow-up. Am J Sports Med 39(11): 2381-2388.

66. Vega J, Golano' P, Pellegrino A, Rabat E, Peña F (2013) All-inside arthroscopic lateral collateral ligament repair for ankle instability with a knotless suture anchor technique. Foot Ankle Int 34(12): 1701-1709.

67. Cottom JM, Rigby RB (2013) The "all inside" arthroscopic brostrom procedure: A prospective study of 40 consecutive patients. J Foot Ankle Surg 52(5): 568-574.

68. Acevedo JI, Mangone P (2015) Arthroscopic Brostrom technique. Foot Ankle Int 36(4): 465-473.

69. Guelfi M, ZamperettiM, PantaloneA, Usuelli FG, Salini V, et al. (2018) Open and arthroscopic lateral ligament repair for treatment of chronic ankle instability: A systematic review. Foot Ankle Surg 24: 11-18.

70. Takao M, Uchio Y, Naito K, Fukazawa I, Ochi M (2005) Arthroscopic assessment for intra-articular disorders in residual ankle disability after sprain. Am J Sports Med 33(5): 686-692.

71. Ferkel RD, Chams RN (2007) Chronic lateral instability: Arthroscopic findings and long-term results. Foot Ankle Int 28(1): 24-31.

72. Hua Y, Chen S, Li Y, Chen J, Li H (2010) Combination of modified Brostro " $m$ procedure with ankle arthroscopy for chronic ankle instability accompanied by intra-articular symptoms. Arthroscopy 26(4): 524-528.

73. Okuda R, Kinoshita M, Morikawa J, Yasuda T, Abe M (2005) Arthroscopic findings in chronic lateral ankle instability: Do focal chondral lesions influence the results of ligament reconstruction? Am J Sports Med 33(1): $35-42$.

74. Hintermann B, Boss A, Scha"fer D (2002) Arthroscopic findings in patients with chronic ankle instability. Am J Sports Med 30(3): 402-409.

75. Girard P, Anderson RB, Davis WH, Isear JA, Kiebzak GM (1992) Clinical evaluation of the modified Brostrom Evans procedure to restore ankle stability. Foot Ankle Int 20(4): 246-252.

76. Mackay GM, Ribbans WJ (2016) The addition of an "internal brace" to augment the Broström technique for lateral ankle ligament instability. Tech Foot Ankle Surg 15(1): 47-56.
77. Evans DL (1953) Recurrent instability of the ankle; a method of surgical treatment. Proc R Soc Med 46(5): 343-344.

78. Snook GA, Chrisman OD, Wilson TC (1985) Long-term results of the Chrisman-Snook operation for reconstruction of the lateral ligaments of the ankle. J Bone Joint Surg Am 67(1): 1-7.

79. Becker HP, Ebner S, Ebner D, Benesch S, Fro"ssler H, et al. (1999) 12-year outcome after modified Watson-Jones tenodesis for ankle instability. Clin Orthop Relat Res (358): 194-204.

80. Castaing J (1962) Apropos of severe sprains of the ankle. Sem Hop Ther Paris 38: 535-537.

81. Buerer Y, Winkler M, Burn A, Chopra S, Crevoisier X (2013) Evaluation of a modified Brostro"m- Gould procedure for treatment of chronic lateral ankle instability: A retrospective study with critical analysis of outcome scoring. Foot Ankle Surg 19(1): 36-41.

82. Jeys LM, Harris NJ (2003) Ankle stabilization with hamstring autograft: A new technique using interference screws. Foot Ankle Int 24(9): 677679.

83. Coughlin MJ, Schenck RC Jr, Grebing BR, Treme G (2004) Comprehensive reconstruction of the lateral ankle for chronic instability using a free gracilis graft. Foot Ankle Int 25(4): 231-241.

84. Schenck RC, Coughlin MJ (2009) Lateral ankle instability and revision surgery alternatives in the athlete. Foot Ankle Clin 14(2): 205-214.

85. Wang B, Xu XY (2013) Minimally invasive reconstruction of lateral ligaments of the ankle using semitendinosus autograft. Foot Ankle Int 34(5): 711-715.

86. Hunt KJ, Phisitkul P, Pirolo J, Amendola A (2015) High ankle sprains and syndesmotic injuries in athletes. J Am Acad Orthop Surg 23(11): 661673.

87. Uys HD, Rijke AM (2002) Clinical association of acute lateral ankle sprain with syndesmotic involvement: A stress radiography and magnetic resonance imaging study. Am J Sports Med 30(6): 816-822.

88. Roemer FW, Joomah N, Niu J, Almusa E, Roger BD Hooghe P, et al. (2014) Ligamentous injuries and risk of associated tissue damage in acute sprains in athletes-A cross-sectional MRI study. Am J Sports Med 42(7): 1549-1557.

89. Morris MW, Rice P, Schneider TE (2009) Distal tibiofibular syndesmosis reconstruction using a free hamstring autograft. Foot Ankle Int 30(6): 506-511.

90. Dekker II RG, Barbosa MP, Kadakia AR (2017) Chronic syndesmotic injuries and reconstruction. Tech Foot \& Ankle 16(3): 141-149.

91. Grass R, Rammelt S, Biewener A, Zwipp H (2003) Peroneus longus ligamentoplasty for chronic instability of the distal tibio fibular syndesmosis. Foot Ankle Int 24(5): 392-397.

92. Espinosa N, Smerek JP, Myerson MS (2006) Acute and chronic syndesmosis injuries: Pathomechanisms, diagnosis and management. Foot Ankle Clin 11(3): 639-657.

93. Pena FA, Coetzee JC (2006) Ankle syndesmosis injuries. Foot Ankle Clin 11(1): 35-50.

94. Olson KM, Dairyko GH Jr, Toolan BC (2011) Salvage of chronic instability of the syndesmosis with distal tibiofibular arthrodesis: functional and radiographic results. J Bone Joint Surg Am 93(1): 66-72.

95. CrimJR, Beals TC, Nickisch F, Schannen A, Saltzman CL (2011) Deltoid ligament abnormalities in chronic lateral ankle instability. Foot Ankle Int 32(9): 873-278.

96. Hintermann B, Boss A, Schafer D (2002) Arthroscopic findings in patients with chronic ankle instability. Am J Sports Med 30(3): 402-409.

97. Buchhorn T, Sabeti Aschraf M, Dlaska CE, Wenzel F, Graf A, et al. (2011) Combined medial and lateral anatomic lateral reconstruction for chronic rotational instability of the ankle. Foot Ankle Int 32(12): 1122-1126. 
98. Ferkel RD, Karzel RP, Del Pizzo W, Friedman MJ, Fischer SP (1991) Arthroscopic treatment of anterolateral impingement of the ankle. Am J Sports Med 19(5): 440-446.

99. Murawski CD, Kennedy JG (2010) Anteromedial impingement in the ankle joint: Outcomes following arthroscopy. Am J Sports Med 38(10): 2017-2024.

100. van Dijk CN (2006) Anterior and posterior ankle impingement. Foot Ankle Clin 11(3): 663-683.

101. Jordan 3rd LK, Helms CA, Cooperman AE, Speer KP (2000) Magnetic resonance imaging findings in anterolateral impingement of the ankle. Skeletal Radiol 29(1): 34-39.

102. Robinson P, White LM, Salonen DC, Daniels TR, Ogilvie-Harris D (2001) Anterolateral ankle impingement: MR arthrographic assessment of the anterolateral recess. Radiology 221(1): 186-190.

103. Duncan D, Mologne T, Hildebrand H, Stanley M, Schreckengaust R, et al. (1998) The usefulness of magnetic resonance imaging in the diagnosis of anterolateral impingement of the ankle. J Foot Ankle Surg 45(5): 304-307.

104. Zengerink M, van Dijk CN (2012) Complications in ankle arthroscopy. Knee Surg Sports Traumatol Arthrosc 20(8): 1420-1431.

105. Ross KA, Murawski CD, Smyth NA, IZwiers NA, Wiegerinck R, et al (2016) Current concept review: Arthroscopic treatment of anterior ankle impingement. J Foot Ankle Surg 23(1): 1-8.

106. Heckman DS, Gluck GS, Parekh SG (2009) Tendon disorders of the foot and ankle. Am J Sports Med 37(3): 614-625.

107. Philibin TM, Landis GS, Smith B (2009) Peroneal tendon injuries. J Am Acad Orthop Surg 17(5): 306-317.

108. Safran MR, O’Malley D Jr, Fu FH (1999) Peroneal tendon subluxation in athletes: New exam technique, case reports, and review. Med Sci Sports Exerc 31(7suppl): S487-S492.

109. Marti R (1977) Dislocation of the peroneal tendons. Am J Sports Med 5(1):19-22

110. Stamatis ED, Karaoglanis GC (2014) Salvage options for peroneal tendon ruptures. Foot Ankle Clin N Am 19(1): 87-95.

111. Walther M, Morrison R, Mayer B (2009) Retromalleolar groove impaction for the treatment of unstable peroneal tendons. Am J Sports Med 37(1): 191-194.

112. Raikin SM, Elias I, Nazarian LN (2008) Intrasheath subluxation of the peroneal tendons. J Bone Joint Surg Am 90(5): 992-999.

113. Boykin RE, Ogunseinde B, McFeely ED, Nasreddine A, Kocher MS (2010) Preliminary results of calcaneofibular ligament transfer for recurrent peroneal subluxation in children and adolescents. J Pediatr Orthop 30(8): 899-929.

114. Kelly RE (1920) An operation for chronic dislocation of the peroneal tendons. Br J Surg 7(28): 502-504.

115. Hu M, Xu X (2018) Treatment of chronic subluxation of the peroneal tendons using a modified posteromedial peroneal tendon groove deepening technique. Foot Ankle Surg 57(5): 884-889.

116. Van BueckenK, Barrack RL, Alexander AH, Ertl JP (1989) Arthroscopic treatment of transchondral talar dome fractures. Am J Sports Med 17(3): 350-356

117. Berndt AL, Harty M (1959) Transchondral fractures (osteochondritis dissecans) of the talus. J Bone Joint Surg Am 41: 988-1020.

118. Lee M, Kwon JW, Choi WJ, Lee JW (2015) Comparison of outcomes for osteochondral lesions of the talus with and without chronic lateral ankle instability. Foot Ankle Int 36(9): 1050-1057.

119. Easley ME, Latt LD, Santangelo JR, Merian-GenastM, Nunley II JA (2010) Osteochondral lesions of the talus. J Am Acad Orthop Surg 18(10): 616-630.
120. O'Loughlin PF, Heyworth BE, Kennedy JG (2010) Current concepts in the diagnosis and treatment of osteochondral lesions of the ankle. Am J Sports Med 38(2): 392-404.

121. Pritsch M, Horoshovski H, Farine I (1986) Arthroscopic treatment of osteochondral lesions of the talus. J Bone Joint SurgAm 68(6): 862865 .

122. Verhagen RA (2005) Prospective study on diagnostic strategies in osteochondral lesions of the talus. Is MRI superior to helical CT? J Bone Joint Surg Br 87(1): 41-46.

123. McGahan PJ, Pinney SJ (2010) Current concepts review: Osteochondral lesions of the talus. Foot Ankle Int 31(1): 90-101.

124. Klammer G, Maquieira GJ, Spahn S, Vigfusson V, Zanetti M, et al. (2015) Natural history of nonoperatively treated osteochondral lesions of the talus. Foot Ankle Int 36(1): 24-31.

125. Chuckpaiwong B, Berkson EM, Theodore GH (2008) Microfracture for osteochondral lesions of the ankle: Outcome analysis and outcome predictors of 105 cases. Arthroscopy 24(1): 106-112.

126. Zengerink M, Struijs PA, Tol JL, van Dijk CN (2009) Treatment of osteochondral lesions of the talus: A systematic review. Knee Surg Sports Traumatol Arthrosc 18(2): 238-246.

127. Cuttica DJ, Smith WB, Hyer CF, Philbin TM, Berlet GC (2012) Arthroscopic treatment of osteochondral lesions of the tibial plafond. J Foot Ankle Int 33(8): 662-668.

128. Kono M, Takao M, NaitoK (2006) Retrograde drilling for osteochondral lesions of the talar dome. Am J Sports Med 34(9): 1450-1456.

129. Taranow WS, Bisignani GA, Towers JD, Conti SF (1999) Retrograde drilling of osteochondral lesions of the medial talar dome. Foot Ankle Int 20(8): 474-480.

130. Robinson DE, Winson IG, Harries WJ (2003) Arthroscopic treatment of osteochondral lesions of the talus. J Bone Joint Surg Br 85(7): 989-993.

131. Choi WJ, Park KK, Kim BS, Lee JW (2009) Osteochondral lesion of the talus: is there a critical defect size for poor outcome? Am J Sports Med 37(10): 1974-1980.

132. Tasto JP, Ostrander R, Bugbee W, Brage M (2003) The diagnosis and management of osteochondral lesions of the talus: Osteochondral allograft update. Arthroscopy 19(Suppl1): 138-141.

133. Liu W, Liu F, Zhao W, Kim JM, Wang Z, et al. (2011) Osteochondral autograft transplantation for acute osteochondral fractures associated with an ankle fracture. Foot Ankle Int 32(4): 437-442.

134. Bisicchia S, Rosso F, Amendola A (2014) Tala rosteochondral defects: Current techniques. Oper Tech Sports Med 22(4): 331-338.

135. Kreulen C, Giza E, Walton J, Sullivan M (2018) Seven-Year Follow-up of Matrix-Induced Autologous Implantation in Talus Articular Defects. Foot Ankle Spl 11(2): 133-137.

136. Hatic So 2nd, Berlet GC (2010) Particulated juvenile articular cartilage graft (DeNovo NT Graft) for treatment of osteochondral lesions of the talus. Foot Ankle Spec 3(6): 361-364.

137. Delman C, Wuellner J, Kreulen C, MD , Lundeen G. MD, Giza E (2018) Particulated autograft cartilage Implantation for the treatment of osteochondral lesions of the talus: A novel technique. Foot Ankle Spl 11(4): 365-371.

138. Ruth CJ (1961) The surgical treatment of injuries of the fibular collateral ligaments of the ankle. J Bone Joint Surg Am 43(2): 229-223.

139. Haraguchi N, Toga H, Shiba N, Kato F (2007) Avulsion fracture of the lateral ankle ligament complex in severe inversion injury: Incidence and clinical outcome. Am J Sports Med 35(7): 1144-1152.

140. Hasegawa A, Kimura M, Tomizawa S, Shirakura K (1996) Separated ossicles of the lateral malleolus. Clin Orthop Relat Res 330: 157-165. 
141. Han SH, Choi WJ, Kim S, Kim SJ, Lee JW (2008) Ossicles associated with chronic pain around the malleoli of the ankle. J Bone Joint Surg Br 90(8): 1049-1054.

142. Chun TH, Park YS, Sung KS (2013) The effect of ossicle resection in the lateral ligament repair for treatment of chronic lateral ankle instability. Foot Ankle Int 34(8): 1128-1133.

143. Diallo J, Wagener J, Schweizer C, Lang TH, Ruiz R, et al. (2018) Intraoperative findings of lateral ligament avulsion fractures and outcome after refixation to the fibula. Foot Ankle Int 39(6): 669-673.

144. Wukich DK, Tuason DA (2011) Diagnosis and treatment of chronic ankle pain. Instr Course Lect 60: 335-350.

145. Mills HJ, Horne G (1987) Fractures of the lateral process of the talus. Aust N Z J Surg 57(9): 643-646.

146. Hawkins LG (1965) Fracture of the lateral process of the talus. J Bone Joint Surg Am 47: 1170- 1175.

147. Ebraheim NA, Skie MC, Podeszwa DA, Jackson WT (1994) Evaluation of process fractures of the talus using computed tomography. J Orthop Trauma 8(4): 332-337.

148. Kou JX, Fortin PT (2009) Commonly missed peritalar injuries. J Am Acad Orthop Surg 17(12): 775-786.

149. Schepers T, Ginai AZ, VanLieshout EM, Patka P (2008) Demographics of extra-articular calcaneal fractures: Including a review of the literature on treatment and outcome. Arch Orthop Trauma Surg 128(10): 10991106.

150. Halm JA, Schepers T (2017) Resection of small avulsion fractures of the anterior process of the calcaneus for refractory complaints. J Foot Ankle Surg 56(1): 135-141.

151. Norfray JF, Rogers LF, Adamo GP, Groves HC, Heiser WJ (1980) Common calcaneal avulsion fracture. Am J Roentgenol 134(1): 119-123.

152. Fallat L, Grimm DJ, Saracco JA (1998) Sprained ankle syndrome: Prevalence and analysis of 639 acute injuries. J Foot Ankle Surg 37(4): 280-285.

153. Robinson KP, Davies MB (2015) Talus avulsion fractures: Are they accurately diagnosed? Injury Int J Care Injured 46(10): 2016-2018.

154. Ramadorai MAJ UE, Beuchel MW, Sangeorzan BJ (2016) Fractures and dislocations of the tarsal navicular. J Am Acad Orthop Surg 24(6): 379 389.

155. Richli WR, Rosenthal DI (1984) Avulsion fracture of the fifth metatarsal: Experimental study of pathomechanics. Am J Roentgenol 143(4): 889-891.

156. Ritchie JD, Shaver JC, Anderson RB, Lawrence SJ, Mair SD (2011) Excision of symptomatic nonunions of fractures of proximal fifth metatarsal avulsion fractures in elite athletes. Am J Sports Med 39(11): 2466-2469.
To Submit Your Article Click Here:

This work is licensed under Creative Commons Attribution 4.0 License

DOI: $10.32474 /$ OSMOAJ.2018.02.000136

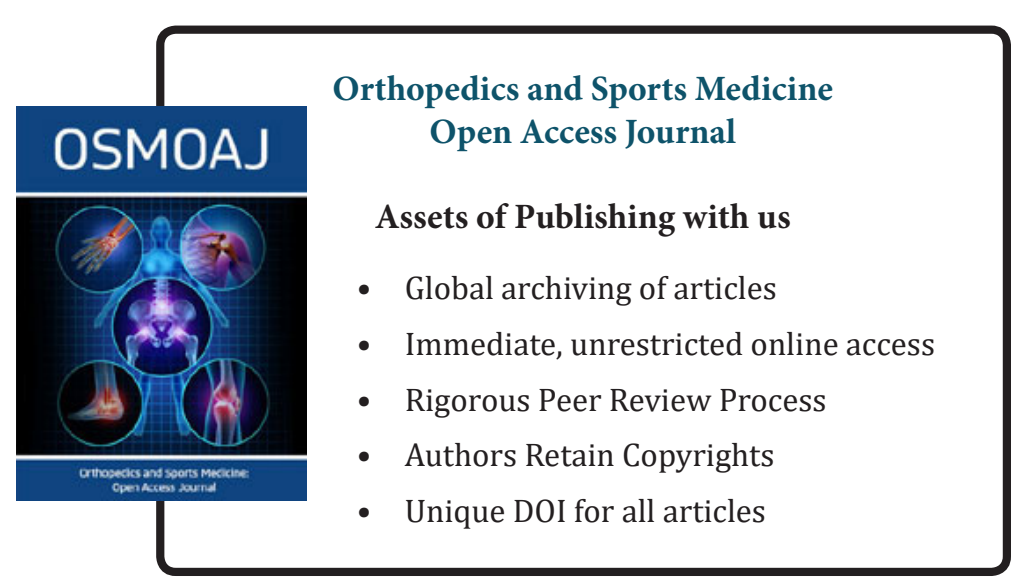

